IRA-International Journal of Education \& Multidisciplinary Studies

ISSN 2455-2526; Vol.06, Issue 01 (2017)

Pg. no. 106-112

Institute of Research Advances

http://research-advances.org/index.php/IJEMS

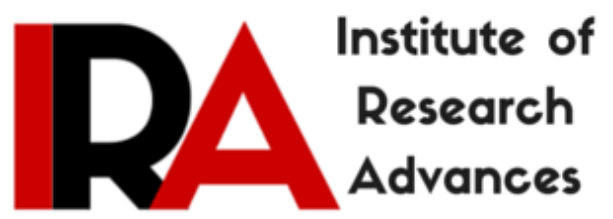

\title{
Learning of Mathematical Concepts in Relation to Spatial Ability and Problem Solving Skills among Secondary School Pupils
}

\section{Dr. J. Shakila}

(M.Sc., M.A. M.Ed. Ph.D.)

Principal, K.G. Prasada Rao - A.N.R College of Education, Gudivada, India.

Type of Review: Peer Reviewed.

DOI: http://dx.doi.org/10.21013/jems.v6.n1.p8

\section{How to cite this paper:}

Shakila, J. (2017). Learning of Mathematical Concepts in Relation to Spatial Ability and Problem Solving Skills among Secondary School Pupils. IRA International Journal of Education and Multidisciplinary Studies (ISSN 2455-2526), 6(1), 106-112.

doi:http://dx.doi.org/10.21013/jems.v6.n1.p8

(C) Institute of Research Advances

(cc) EY-NC

This work is licensed under a Creative Commons Attribution-Non Commercial 4.0 International License subject to proper citation to the publication source of the work.

Disclaimer: The scholarly papers as reviewed and published by the Institute of Research Advances (IRA) are the views and opinions of their respective authors and are not the views or opinions of the IRA. The IRA disclaims of any harm or loss caused due to the published content to any party. 


\section{ABSTRACT}

Mathematics with all its branches plays an important role in everyday life. It is created to investigate the whole range of knowledge. Learning mathematics is basically a constructive process, which means that pupils gather, discover, create mathematical knowledge and skills mainly in the course of some social activity that has purpose consequently mathematics classroom instruction should move away from the information transmission model. Meaningful and authentic context should play a crucial role in mathematics learning and teaching, therefore, we need an integrated approach to mathematics teaching.

Problem solving is an integral part of developmental activities and provides opportunities for children to practice what they have learned by applying their learning situations. The amount of practice needed by any learner is reduced if he understands the concepts and skills to be practiced. How can we make our students good problem solvers in mathematics? This is possible only when we make mathematics education more meaningful and interesting. Mathematical abilities like logical thinking, rational reasoning, concentration of mind, orderly presentation, precision and accuracy, analytical and inductive skills, and above all general problem solving abilities. So the present study is intended to learning of mathematical concepts in relation to problem solving skills among secondary school pupils.

Key words: Learning Mathematical Concepts, Problem Solving Skills, Secondary School Pupils.

Introduction: Mathematics is a subject of problems. Its teaching and learning demands solving of innumerable problems. Efficiency and ability in solving problems guarantee the success in learning of the mathematical concepts. Learning mathematics is basically a constructive process, which means that pupils gather, discover, Create mathematical knowledge and skills. Problem solving skill is one of the most important life skills. Life is full of problems and challenges. It provides the ability to face the day-to-day complex situations or problems successfully and to adjust them efficiently. The pupil can develop the skills of problem solving at the school level. School has changed its purpose from just academic empowerment to life skills empowerment, which is much more comprehensive and useful in the world today.

Review of Related Literature: In the present study the investigator has reviewed the researches done in the field of learning of mathematical concepts in relation to problem solving skills among secondary school pupils. SUMANGALA V. and MALINI, P.M. (1998) studied mastery learning strategy and achievement in mathematics at secondary school level. GURUSAMY, S. (1991) did a diagnostic study of the errors committed by students of standard IX in solving problems in Geometry .YADAV, P.S. (1984) studied the effect of Mastery Learning Strategy on pupils' achievement in mathematics, WELLS (1981) in his study on "The processes involved in the activities of computer programming and mathematical problem solving", MAINKA (1982) attempted to determine the ability of children to acquire mathematical concepts.' HULL (1979) in a study on "developing competency with problem solving ability in mathematics". Based on the above reviews the investigator also intended to study the learning mathematical concepts in relation to problem solving skills among secondary school pupils.

Need and Importance of the Study: Mathematics helps to promote logical thinking, develops truthfulness in thinking, exactness and clarity of thought and promotes power of concentration. Problem solving skill involves the application of thinking and reasoning to various kinds of problems encountered in life. Life is ever changing day by day. Not only the individual is facing numerous problems in the society. To overcome this situation it is important to develop problem solving skills in students. IX class is the good representative class. This is the stage where the pupils have both physical and mental maturity. . In this process, secondary school pupils gain more problem solving skills and lead day to day life by solving the problems they are facing. Therefore secondary school children's learning of 
mathematical concepts in relation to problem solving skills among secondary school pupils is found very significant for the present study

Title of the study: "Learning of mathematical concepts in relation to problem solving skills among secondary school pupils."

Objectives of the Study:

1. To find out the level of learning of mathematical concepts of secondary school pupils and classify them.

2. To find out the level of problem solving skills among secondary school pupils and classify them.

3. To find out the level of spatial ability among secondary school pupils and classify them

4. To find out the relationship among the learning of mathematical concepts, problem solving skills and spatial ability among secondary school pupils.

5. To find out the influence of the learning of mathematical concepts among secondary school pupils differ with respect to following variables.

$>$ Gender (Boys/ Girls )

$>$ Location (Urban/ Rural )

$>$ Status of the school (Govt / Private )

\section{Hypotheses of the Study:}

1. Secondary school pupils differ in their levels of learning of mathematical concepts.

2. Secondary school pupils differ in their levels of problem solving skills.

3. There would be no significant relationship between the learning of mathematical concepts and problem solving skills.

\section{Sample of the Study:}

A sample is a collection of objects or individuals of characteristics, which are found in the Population. Sampling is the process of selecting a sample form the population. For the present study the investigator has taken up a stratified random sample of 31 schools are categorized in to Government, Private, aided, private unaided and local body schools. And 620 IX class pupils of Krishna district. The researcher thought that normative survey method is suitable to collect data through questionnaires and tests to pupils on learning of mathematical concepts and problem solving skills. The scores were compared variable wise to find out if there are any significant variations.

\section{Tool of the Study:}

Mathematical concepts test: A test was constructed on mathematical concepts in practical situations on three areas (Mensuration, Sets and Symmetry) containing 60 items were prepared for tryout from VIII class mathematics text book by the investigator. The difficulty level and discriminating power of each test item were calculated. Thus out of 60 items, 12 items were deleted owing to their poor discriminating power and the remaining 48 items were retained for the final test.

Problem Solving Skill: The tool constructed by Dr. P. Martutham \& Dr. C.G Venkatesha Murthy of R.I.E was adopted. The present questionnaire contains 22 items. Problem solving skills scale includes three sub skills - approach avoidance character of the person in problem situations, problem solving confidence and personal control. This scale contains 13 positive items and 9 negative items. All the 22 items were retained as they were found valid. Internal consistency value was calculated after the tryout of the scale. Cronbach Alpha was applied and the value of reliability was found 0.60112 . As the test is found (P. No 349, Garret) reliable, it is valid.

Data Collection Process: The required data were collected from 31 schools of Krishna District. The investigator personally went for data collection with prior permission from the heads of the institutions. 
The investigator spent a day in each school in order to conduct the tools of the study one by one with short intervals. Before conducting the test, detailed instructions were given to the students. All the requirements were provided to the students for writing the test.

Limitations of the Study: The study is limited to

1. The following mathematical concepts- Mensuration (Arithmetic), Sets (Algebra) and Symmetry( Geometry) drawn from VIII Class state syllabus only.

2. The sample is limited to Krishna district only.

3. The size of the sample is 620 pupils of IX Class only.

4. The sample consists of only Telugu medium students.

Data Analysis:

Objective 1: To find out the level of mathematical concepts of the secondary school pupils and to classify them.

Table 1: The Mean, \% of Mean, S.D and 1/5 of Mean of the total sample in learning of mathematical concepts.

\begin{tabular}{|c|c|c|c|c|}
\hline $\mathrm{N}$ & Mean & \% of Mean & SD & 1/5th of Mean \\
\hline 620 & 21.5145 & 44.82 & 7.2270 & 4.3029 \\
\hline
\end{tabular}

Interpretation: High school pupils are found to have average level of learning of mathematical concepts since $1 / 5^{\text {th }}$ of mean value is less than the S.D value. The sample of pupils is heterogeneous in learning of mathematical concepts.

Table 2: Classification of pupils on the basis of their level of learning of mathematical concepts.

\begin{tabular}{|c|c|c|c|}
\hline Category & Scale & No. of students & Percentage \\
\hline Very Low & $0-9$ & 11 & 1.77 \\
\hline Low & $10-19$ & 247 & 39.83 \\
\hline Average & $20-29$ & 292 & 47.09 \\
\hline High & $30-39$ & 51 & 8.25 \\
\hline Very High & $40-48$ & 19 & 3.06 \\
\hline
\end{tabular}

Interpretation: Most of the pupils, nearly half of them have average level of learning of mathematical concepts. Nearly two fifths of them have low level of learning and eighty seven percent of the pupils have only low and average learning of mathematical concepts.

Objective 2: To find out the level of problem solving skills among secondary schools pupils and to classify them.

Table 3: The mean, \% of mean, S.D and $1 / 5^{\text {th }}$ mean of the total sample in problem solving skill.

\begin{tabular}{|c|c|c|c|c|}
\hline $\mathbf{N}$ & Mean & \% mean & S.D & 1/5th mean \\
\hline 620 & 94.4 & 71.51 & 12.53 & 18.88 \\
\hline
\end{tabular}


Interpretation: The pupils are found to have high problem solving skill and the sample is found to be homogeneous since $1 / 5^{\text {th }}$ of mean value is more than the S.D value.

Table 4: Classification of pupils on the basis of their level of problem solving skill

\begin{tabular}{|c|c|c|c|}
\hline Category & Score Scale & No. of students & Percentage \\
\hline Very Low & $22-43$ & Nil & 0 \\
\hline Low & $44-65$ & 2 & 0.322 \\
\hline Average & $66-88$ & 180 & 29.03 \\
\hline High & $89-110$ & 356 & 57.41 \\
\hline Very High & $111-132$ & 82 & 13.22 \\
\hline
\end{tabular}

Interpretation: More than half of the total sample of the secondary school pupils have high problem solving skill.

Objective : 3 To find out the spatial ability among secondary school pupils and classify them.

Table 3. The mean, $\%$ of mean, $1 / 5^{\text {th }}$ mean and S.D value of the total sample in spatial ability test

\begin{tabular}{|c|l|c|c|c|}
\hline $\boldsymbol{N}$ & Mean & \% of mean & S.D & $\mathbf{1 / 5}^{\text {th }}$ of Mean \\
\hline 620 & 56.43 & 57 & 14.33 & 11.28 \\
\hline
\end{tabular}

\section{Interpretation:}

The secondary school pupils are found to be average spatial ability. The pupils are found to be heterogeneous in their spatial ability since the $1 / 5^{\text {th }}$ of Mean value is less than the S.D value.

Table 4: Classification of pupils on the basis of their level of spatial ability test.

\begin{tabular}{|l|l|l|l|}
\hline Category & Scale & $\begin{array}{l}\text { No. of } \\
\text { students }\end{array}$ & Percentage \\
\hline Very low & $0-19$ & 13 & 2.096 \\
\hline Low & $20-39$ & 48 & 7.741 \\
\hline Average & $40-59$ & 284 & 45.80 \\
\hline High & $60-79$ & 249 & 40.16 \\
\hline Very High & $80-99$ & 26 & 4.19 \\
\hline
\end{tabular}

\section{Interpretation :}

Most of the pupils have average level of spatial ability. Two fifths of the sample of pupils are found having good spatial ability. 


\section{Objective :4}

To find out the relation between learning of mathematical concepts, problem solving skills and spatial ability of secondary school pupils.

Table 5: Relationship among the Mathematical Concepts, Problem solving skill and spatial ability.

\begin{tabular}{|l|l|l|c|c|}
\hline S.NO & \multicolumn{1}{|c|}{ Variable } & N & $\boldsymbol{d f}$ & $\boldsymbol{R}$ value \\
\cline { 1 - 2 } 1. & Mathematical concepts & 620 & \multirow{2}{*}{$620-2=618$} & \multirow{2}{*}{$0.4634^{* *}$} \\
\cline { 1 - 3 }. & Problem solving skill & 620 & & \\
\cline { 1 - 3 }. & Spatial ability test & 620 & & \\
\hline
\end{tabular}

Interpretation: As the ' $\mathrm{R}$ ' value is found significant it can be inferred that there is significant positive correlation among the learning of mathematical concepts, problem solving skills and spatial ability of secondary school pupils.

Discussion : Mathematics develops problem solving ability to carry on abstract thinking, reasoning, visualizing and logically dealing with any problem the students encounter with. They develop inherent discipline to approach the problem, instead of avoiding the problem and space perception and depth perception as they develop confidence in solving mathematical problems in class rooms. They try to approach any problem systematically, analyse the problem systematically whether it is classroom problem or problems of life. This may be the reason for the observed positive correlation found among the learning of mathematical concepts, problem solving skill and spatial ability.

Objective 4: To find out the influence of the learning of mathematical concepts among secondary school pupils differ with respect to Gender, Location, Status of the school.

Table 6: Table showing the variable wise distribution mean, S.D, t-value for learning mathematical concepts.

\begin{tabular}{|c|c|c|c|c|c|c|}
\hline S. No & Variable & Type & $\mathrm{N}$ & Mean & S.D & t-value \\
\hline \multirow[t]{2}{*}{1} & \multirow[t]{2}{*}{ Gender } & Boys & 270 & 21.786 & 8.676 & \multirow[t]{2}{*}{$0.7857 \mathrm{NS}$} \\
\hline & & Girls & 350 & 21.303 & 5.864 & \\
\hline \multirow[t]{2}{*}{2} & \multirow[t]{2}{*}{ locality } & Urban & 280 & 20.768 & 5.725 & \multirow[t]{2}{*}{$2.100 *$} \\
\hline & & Rural & 340 & 21.756 & 5.956 & \\
\hline \multirow[t]{2}{*}{3} & \multirow{2}{*}{$\begin{array}{l}\text { Status of the } \\
\text { school }\end{array}$} & Govt & 342 & 57.9 & 12.8 & \multirow[b]{2}{*}{$2.83 * *$} \\
\hline & & Private & 278 & 54.6 & 15.9 & \\
\hline
\end{tabular}

\section{Interpretation:}

Learning mathematical concepts have not significantly varied with Gender. It was found that locality, status of the school influences the secondary school pupils. 


\section{Conclusion:}

Mathematics develops problem solving ability to carry on abstract thinking, reasoning, visualizing and logically dealing with any problem the students encounter with. They develop inherent discipline to approach the problem, instead of avoiding the problem and space perception and depth perception as they develop confidence in solving mathematical problems in class rooms. They try to approach any problem systematically, analyse the problem systematically whether it is classroom problem or problems of life. This may be the reason for the observed positive correlation found among the learning of mathematical concepts, problem solving skill and spatial ability. But it is sad to find that the IX class pupils have only average level of learning of mathematical concepts. Another appreciable finding is that most of the secondary school pupils have high level of problem solving skills.

Most of the secondary school pupils are in the age group of $13+$ and this is the beginning of teenage. They are in the formal operational stage of cognitive development. After one more year, they enter X class which is the most importance stage in the educational life of students as it propels them into the realm of higher education. Therefore efforts are to be made caring these directions to improve learning mathematical concepts and problem solving skills by focusing more on concepts in mathematics related to real life problems rather than mere formulae and exercise and re-orienting the teachers and parents towards these aspects.

\section{Educational Implications:}

1. This study will help to find out ability of the high school pupils in different areas of learning of mathematical concepts.

2. This study will enable the teacher to identify the need and importance of spatial ability.

3. This study will help the teachers to know about the ability of the high school children in applying the mathematical knowledge in problem solving skill.

4. This study will help the mathematics teachers to focus their attention on their teaching of mathematical concepts.

5. This study will direct the teachers to develop better teaching strategies to care the pupil's comprehension of mathematical concepts.

\section{References:}

1. AGARWAL, J.C. (1966): Educational and Research, New Delhi. Arya Book Depot.

2. ANICE JAMES (2005): Teaching of Mathematics, Hyderabad.

3. GIRUSWAMY,S. (1991) : A diagnostic study of the errors committed by students of standard IX in solving problems in geometry in M.B BUCH (Ed), Fifth survey of research in Edn, (Vol.1) (1989-93), New Delhi, NCERT.

4. HULL (1979): developing competency with problem solving ability in mathematics in M.B. BUCH (Ed), Third survey of research in Edn, (Vol.1) (1978-83), New Delhi, NCERT.

5. MANIKA (1982): The ability of children to acquire mathematical concepts and to evaluate understanding and the acquisition of mathematical concepts of pupils in M.B. Buch (ed), Third survey of research in Edn, (Vol.1) (1978-83), New Delhi, NCERT.

6. SUMANGALA, (1995): study the relationship between mathematical aptitude and achievement in mathematics for IX class students in M.B.BUCH, (Ed) Sixth survey of educational research (19932000) [Vol:2] New Delhi, NCERT.

7. YADAV,P.S. (1984) : The effect of mastery learning strategy on pupils achievement in mathematics, their self concept and attitude towards mathematics in M.B BUCH (Ed), Fourth survey of research in Edn, (Vol.1) (1983-88), New Delhi, NCERT.

\section{Websites:}

1. http://shodhganga.inflibnet.ac.in/bitstream/10603/8092/6/06_list\%20of\%20table.pdf

2. http://shodhganga.inflibnet.ac.in/bitstream/10603/8092/11/11_chapter\%204.pdf 